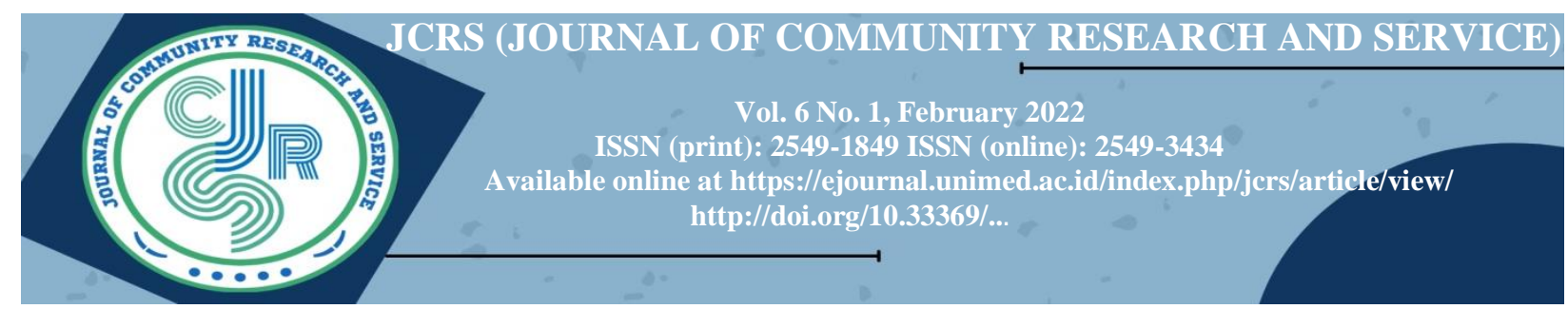

\title{
Pengaruh Job Enrichment, Reward dan Teamwork Terhadap Employee Engagement Pada PT Nusantara Berlian Motor
}

\author{
Teguh Wahyono \\ Manajemen, Universitas Pembangunan Panca Budi, Medan, INDONESIA \\ teguhwahyono753@gmail.com
}

\begin{abstract}
The purpose of this study is to ascertain the effect of Job Enrichment, Reward and Teamwork on Employee Engagement at PT Nusantara Berlian Motor. The sample in this study were all employees of PT Nusantara Berlian Motor, totaling 45 employees. This study was done between July and November 2020. Sources of data were collected through questionnaires. This study uses quantitative data with multiple linear regression analysis model. The findings indicated that Job Enrichment and Reward had a positive and significant effect on Employee Engagement at PT Nusantara Berlian Motor partially. Teamwork does not have a significant effect on Employee Engagement at PT Nusantara Berlian Motor partially. Job Enrichment, Reward, and Teamwork simultaneously have a positive and significant effect on Employee Engagement at PT Nusantara Berlian Motor.
\end{abstract}

Keywords: Job Enrichment, Reward, Teamwork, Employee Engagement

Article history: Received:14-12-2021; Revised: 20-12-2021; Accepted: 16-02-2022; Available online: 26-02-2022 How to cite this article: Wahyono, T. (2022) Pengaruh Job Enrichment, Reward dan Teamwork Terhadap Employee Engagement Pada PT Nusantara Berlian Motor. Journal of Community Research and Service,6(1), .

https://doi.org/10.14710/ijred.X.X.Xxx-Xxx

\section{Pendahuluan}

Perkembangan di dunia otomotif sangat berkembang dengan pesat terutama di bidang kendaraan roda empat. Hal ini bisa diliat dari mayoritas individu atau mayoritas rumah masyarakat yang memiliki kendaraan roda empat minimal satu kendarran roda empat. Showroom resmi menjadi salah satu sektor yang dipercaya untuk melakukan setiap trasanksi jual beli maupun untuk melakukan perawatan berkala atau perbaikan-perbaikan kendaraan roda empat yang mengalami masalah cukup berat pada kendaraan tersebut. Dalam meraih keunggulan bersaing dengan kompetitor lainnya, setiap Showroom bukan hanya mampu untuk memberikan kualitas produk yang baik, tetapi juga harus memiliki kualitas sumber daya manusia atau sikap kerja yang dimiliki karyawan yang dituntut harus mampu memberikan pelayanan yang memuaskan kepada costumer yang akan membeli produk maupun jasa yang di tawarkan. Engagement merupakan faktor sikap kerja yang berkontribusi paling besar terhadap predictor kinerja organisasi [2]. Perusahaan membutuhkan staf yang aktif dan berdedikasi, yaitu karyawan yang terlibat dalam pekerjaannya [1]. Menurut [8], engagement terkait dengan persepsi diri seseorang. Karena itu, setiap perusahaan membutuhkan orang-orang yang secara emosional diinvestasikan dalam pekerjaan mereka atau disebut employee engagement [1].

Employee engagement yang baik terhadap karyawan dilakukan agar karyawan merasa diperhatikan dan dihargai setiap melakukan tanggung jawabnya, employee engagement dapat berdampak negatif pada proses bisnis organisasi, yang mengakibatkan penurunan kinerja organisasi [11]. Pengkayaan pekerjaan (job enrichment) menjadi salah satu faktor yang mempengaruhi employee engagement. Job enrichment adalah metode merancang pekerjaan yang mencakup berbagai konten pekerjaan, peningkatan tingkat pengetahuan dan kemampuan, dan rasa kepemilikan dan kendali yang lebih besar atas bagaimana pekerjaan direncanakan, diarahkan, dan dipantau. [7] mengungkapkan bahwa pengayaan pekerjaan merupakan 
pondasi inspirasi bagi pekerja yang mengarah pada kinerja yang berorientasi pada tujuan.

Job enrichment ditentukan oleh aspek pekerjaan, yang meliputi variasi keterampilan (skill variety), identitas tugas (task identity), signifikansi tugas (task significant), otonomi (autonomy), dan umpan balik pekerjaan (feedback from the job itself). Skill variety mengacu pada pekerjaan yang memerlukan berbagai kegiatan, task identity mengacu pada penyelesaian pekerjaan yang mencakup semua tahap pekerjaan, task significant mengacu pada dampak pekerjaan pada lingkungan eksternal, autonomy mengacu pada tingkat kontrol pekerja atas bagaimana pekerjaan mereka dilakukan, dan feedback from the job itself mengacu pada umpan balik yang diberikan. peningkatan kinerja pegawai. Ketika lima kriteria ini terpenuhi, itu menandakan bahwa tugas telah ditingkatkan. Menurut Branham dan Hirschfeld di [10] juga mengatakan bahwa kerja sama teamwork menjadi salah satu faktor yang mempengaruhi employee engagement dapat berjalan baik dan berhasil. Teamwork adalah sekelompok orang dengan berbagai kemampuan, pengalaman, bakat, dan latar belakang yang datang bersama dan bekerja menuju tujuan bersama [6]. Sementara itu, [12] menyatakan bahwa teamwork adalah praktik bekerja dalam kelompok dengan peran yang beragam, fokus pada tugas dan masa depan, serta terlibat dalam komunikasi yang intens dan konstruktif. Keadaan teamwork yang baik dari suatu perusahaan akan menghasilkan kondisi kerja yang menyenangkan bagi karyawannya.

\section{Metode}

Dengan menggunakan data primer, penelitian ini menggunakan teknik kuantitatif asosiatif. Untuk menguji hipotesis yang telah ditetapkan, peneliti menggunakan metode kuantitatif untuk meneliti populasi atau sampel tertentu, mengumpulkan data dengan menggunakan instrumen penelitian, dan menganalisis data kuantitatif atau statistik. [9].

Penelitian ini dilakukan di PT Nusantara Berlian Motor yang terletak di Jl. Gagak Hitam Ringroad No. 35 A Medan. Populasi dan sampel dalam penelitian ini adalah seluruh karyawan PT Nusantara Berlian Motor sebanyak 45 orang. Teknik pengumpulan data pada penelitian ini adalah: 1) Angket (kuisioner), adalah teknik pengumpulan data dimana seorang peneliti membagikan sejumlah kertas berisi pertanyaanpertanyaan yang harus dijawab oleh responden. 2) Wawancara, adalah teknik pengumpulan data yang digunakan dengan cara tanya jawab antara dua pihak untuk memperoleh data, keterangan pendapat, atau suatu hal. 3) Studi pustaka, adalah teknik pengumpulan data yang digunakan dengan cara menelaah bukubuku, catatan dan laporan yang berhubungan dengan penelitian. Teknik analisis data pada penelitian ini adalah sebagai berikut:

1) Uji Asumsi Klasik. Uji asumsi klasik adalah persyaratan statistik yang harus dipenuhi pada analisi linier berganda yang berbasis Ordinary Least Square (OLS). Uji asumsi klasik yang digunakan didalam penelitian ini adalah uji normalitas, uji multikolinearitas, uji heteroskedastisitas. Pengujian yang diperlukan dalam penelitian ini, sebagai berikut:

a. Uji Normalitas. Dalam model regresi, uji normalitas menentukan apakah variabel independen dan dependen - atau keduanya - terdistribusi secara teratur [5]. Jika suatu variabel tidak terdistribusi normal, temuan uji statistik akan berkurang. Uji Kolmogorov Smirnov One Sample dapat digunakan untuk menentukan normalitas data, dengan syarat hasil signifikan lebih besar dari 5\% atau 0,05 yang menunjukkan bahwa data berdistribusi normal. Sedangkan jika hasil uji One Sampe Kolmpgorov Smirnov kurang dari 5\% atau 0,05 maka data tidak mengikuti distribusi normal.

b. Uji Multikolinearitas. Digunakan untuk mengetahui ada tidaknya hubungan antara variabel terikat dan variabel bebas dalam model regresi dengan melakukan uji multikolinearitas [5]. Dampak dari multikolinearitas ini adalah sampel memiliki jumlah variabel yang banyak. Dengan kata lain, jika kita menguji t-tabel, t-hitung kita akan lebih rendah dari t-tabel. Tidak ada hubungan linier antara faktor-faktor independen yang mempengaruhi variabel dependen dan variabel dependen itu sendiri. Nilai tolerance dan nilai variance inflaction factor (VIF) dapat digunakan untuk mengetahui ada tidaknya multikolinearitas dalam model regresi. Variabilitas dari variabel independen yang dipertimbangkan, yang tidak dapat dijelaskan oleh variabel independen lainnya, diukur dengan nilai tolerance. Dengan kata lain, karena VIF $=1 /$ toleransi, nilai toleransi yang rendah menunjukkan derajat kolinearitas yang tinggi. Nilai VIF harus lebih besar dari 10 untuk melewati titik batas.

c. Uji Heteroskedasitas. Model regresi dievaluasi dengan menggunakan uji heteroskedastisitas untuk melihat apakah residual satu pengamatan berbeda secara signifikan dengan residual yang JCRS (Journal of Community Research and Service), 6(1), 2022 
lain. [3]. Model regresi yang baik adalah tidak adanya gejala heteroskedasitisitas. Jika tidak terlihat pola dan titik-titik pada sumbu Y berjarak sama di bawah dan di atas 0 , maka tidak terjadi heteroskedastisitas.

2) Regresi Linier Berganda. Analisis regresi linier berganda digunakan dalam penelitian ini. Analisis dilakukan untuk mengetahui pengaruh variabel independen terhadap variabel dependen. Model matematika berikut yang digunakan:

$$
\mathrm{Y}=\alpha+\beta 1 \mathrm{X} 1+\beta 2 \mathrm{X} 2+\beta 3 \mathrm{X} 3+\mathrm{e}
$$

3) Uji Hipotesis, pengujian yang diperlukan pada penelitian ini, sebagai berikut:

a. Uji Simultan. (Uji F) Pengujian simultan digunakan untuk menentukan apakah faktor independen mempengaruhi variabel dependen secara bersamaan atau bersamaan [5]. Tingkat kepercayaan yang digunakan adalah 5\%. Jika nilai $\mathrm{F}$ yang diperkirakan melebihi nilai $\mathrm{F}$ tabel, hipotesis alternatifnya adalah bahwa semua faktor independen berpengaruh signifikan terhadap variabel dependen pada saat yang bersamaan. (Gunjarati, 2011).

b. Uji Parsial (Uji t). Untuk setiap variabel independen, uji-t individual dapat digunakan untuk menetapkan dampaknya terhadap variabel dependen. Apakah variabel job enrichment (X1), reward (X2), dan teamwork (X3) berpengaruh terhadap employee engagement (Y).

c. Koefisien Determinasi (R2). Kemampuan model dalam menjelaskan perubahan variabel terikat diukur dengan koefisien determinasinya (R2) [4]. Dalam statistik, koefisien determinasi berkisar antara 0 sampai 1 . Setiap variabel independen yang memiliki pengaruh kecil terhadap variabilitas variabel dependen memiliki nilai R2 yang rendah.

\section{Findings and Discussion}

\section{Histogram}

Dependent Variable: EMPLOYEE_ENGAGEMENT(Y)

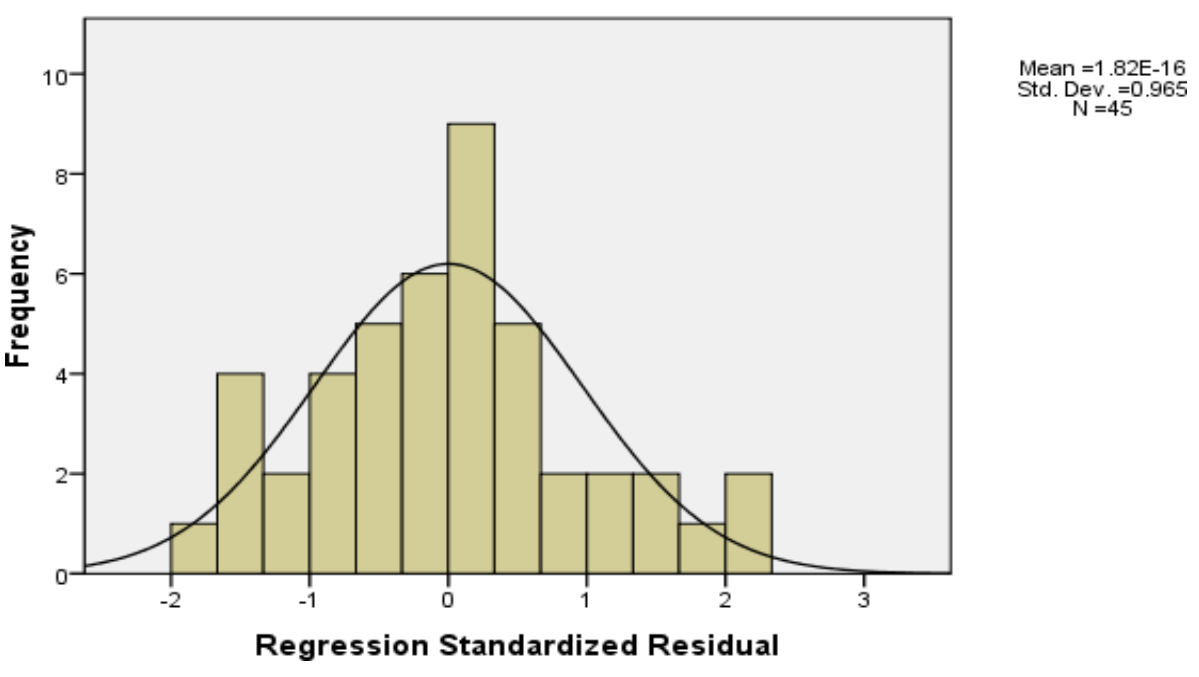

Gambar 1. Histogram Normal.

Sumber: Hasil Pengolahan dengan SPSS 16.0 (2022)

Berdasarkan Gambar 1. hasil pengujian normalitas histogram memiliki garis yang membentuk lonceng yang dapat diasumsikan bahwa data berdistribusi normal dan variabel dapat diuji. 


\section{Normal P-P Plot of Regression Standardized Residual}

\section{Dependent Variable: EMPLOYEE_ENGAGEMENT(Y)}

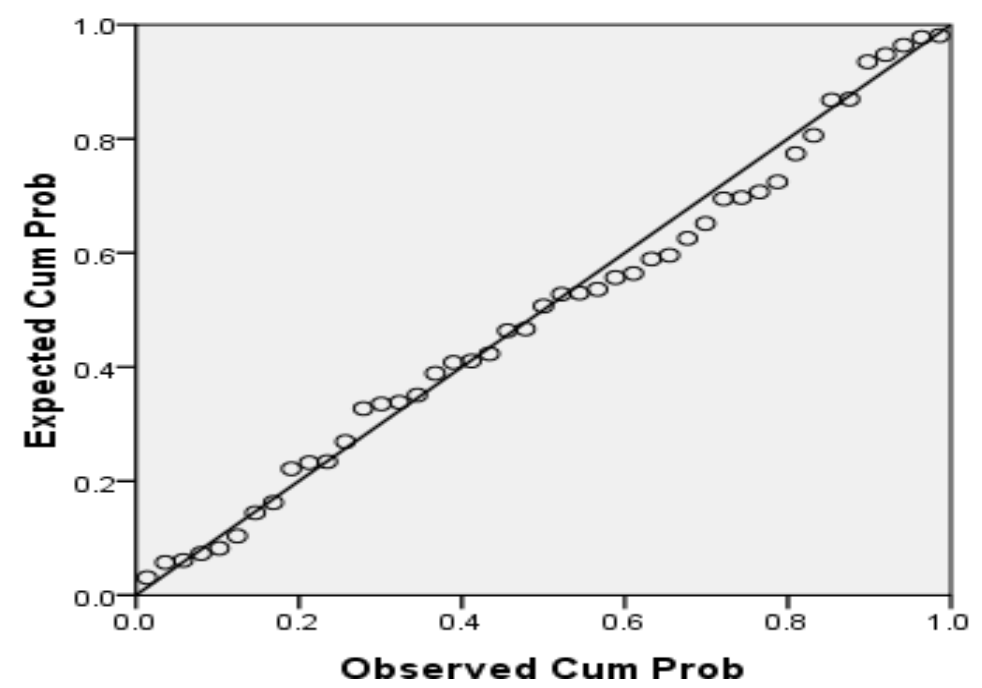

Gambar 2. Normal Plot.

Sumber: Hasil Pengolahan dengan SPSS 16.0 (2022)

Berdasarkan Gambar 2, hasil uji normalitas data menunjukkan bahwa distribusi data berpusat pada garis diagonal dan tidak ada yang menyebar jauh darinya, menunjukkan bahwa data berdistribusi normal dan variabel dapat dievaluasi.

Tabel 1. Uji Normalitas.

One-Sample Kolmogorov-Smirnov Test

\begin{tabular}{|ll|r|}
\hline & & UnstandardizedResidual \\
\hline $\mathrm{N}$ & & 45 \\
Normal Parameters $^{\mathrm{a}}$ & Mean & 0.0000000 \\
& Std. Deviation & 4.47744367 \\
Most Extreme Differences & Absolute & 0.068 \\
& Positive & 0.068 \\
& Negative & -0.055 \\
Kolmogorov-Smirnov Z & & 0.459 \\
Asymp. Sig. (2-tailed) & & 0.984 \\
\hline
\end{tabular}

a. Test distribution is Normal.

Sumber: Hasil Pengolahan dengan SPSS 16.0 (2022)

Berdasarkan Tabel 1, menunjukkan bahwa nilai uji Kolmogorov-Smirnov Z sebesar 0,459 lebih besar dari nilai yang disepakati yaitu 0,05 . Karena nilai signifikan lebih besar dari 0,05 , data ditemukan berdistribusi normal menggunakan uji Kolmogorov-Smirnov $\mathrm{Z}$ dan dapat dikatakan telah memenuhi persyaratan untuk digunakan. 
Tabel 2. Uji Multikolinearitas.

\section{Coefficients $^{\mathbf{a}}$}

\begin{tabular}{|c|c|c|c|}
\hline \multirow{2}{*}{\multicolumn{2}{|c|}{ Model }} & \multicolumn{2}{|c|}{ Collinearity Statistics } \\
\hline & & Tolerance & VIF \\
\hline \multirow[t]{4}{*}{1} & (Constant) & & \\
\hline & Job_Enrichment (X1) & .936 & 1.068 \\
\hline & Reward (X2) & .979 & 1.022 \\
\hline & Teamwork (X3) & .921 & 1.086 \\
\hline
\end{tabular}

a. Dependent Variable: Employee_Engagement(Y) Sumber: Hasil Pengolahan dengan SPSS 16.0 (2022)

Berdasarkan 2, uji multikolinearitas nilai dapat dilihat pada kolom VIF. Variabel job enrichment memiliki nilai VIF sebesar 1,068. Variabel reward memiliki VIF 1,022. Variabel teamwork memiliki VIF 1,086. Tidak ada bukti multikolinearitas karena semua nilai VIF kurang dari 10 pada variabel.

Scatterplot

Dependent Variable: EMPLOYEE_ENGAGEMENT(M)

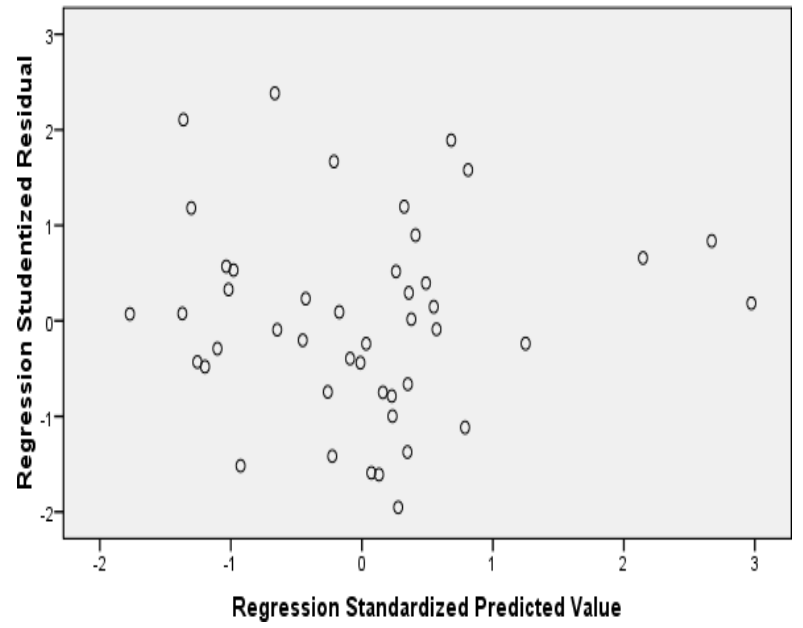

Gambar 3. Uji Heteroskedasitas.

Sumber: Hasil Pengolahan dengan SPSS 16.0 (2022)

Menurut Gambar 3, pola yang tersebar tersebar tidak menciptakan pola yang berbeda. Selanjutnya, tidak terjadi heteroskedastisitas jika titik-titik sumbu Y berjarak seragam di atas dan di bawah nol. 
Tabel 3. Uji Regresi Linear Berganda.

\section{Coefficients $\mathbf{a}^{\mathbf{a}}$}

\begin{tabular}{|c|c|c|c|c|}
\hline \multirow{2}{*}{\multicolumn{2}{|c|}{ Model }} & \multicolumn{2}{|c|}{ Unstandardized Coefficients } & \multirow{2}{*}{$\begin{array}{c}\begin{array}{r}\text { Standardized } \\
\text { Coefficients }\end{array} \\
\text { Beta }\end{array}$} \\
\hline & & B & Std. Error & \\
\hline \multirow[t]{4}{*}{1} & (Constant) & 14.083 & 4.091 & \\
\hline & Job_Enrichment (X1) & 0.373 & 0.158 & 0.334 \\
\hline & Reward (X2) & 0.273 & 0.119 & 0.319 \\
\hline & Teamwork (X3) & 0.007 & 0.136 & 0.008 \\
\hline
\end{tabular}

a. $\quad$ Dependent Variable: Employee_Engagement (Y)

Sumber: Hasil Pengolahan dengan SPSS 16.0 (2022)

Berdasarkan Tabel 3, diperoleh hasil konstanta dari Employee Enggament (Y) sebesar 14.083. Nilai regresi dari Job Enrichment sebesar 0,373, nilai regresi dari Reward sebesar 0,273, dan nilai regresi dari Teamwork sebesar 0,007.

$$
\mathrm{Y}=14.083+0,373 \mathrm{X} 1+0,273 \mathrm{X} 2+0,007 \mathrm{X} 3+\mathrm{e}
$$

Employee engagement memiliki nilai 14.083 jika variabel independen dianggap 0 (nol). Employee engagement (Y) akan naik sebesar 0,373 unit jika job enrichment meningkat satu unit. Employee engagement $(\mathrm{Y})$ akan naik sebesar 0,273 poin jika kompensasi dinaikkan satu unit. Employee engagement (Y) akan meningkat sebesar 0,007 persen jika teamwork meningkat sebesar satu unit.

Tabel 4. Hasil Uji t.

Coefficients $\mathbf{a}^{\mathbf{a}}$

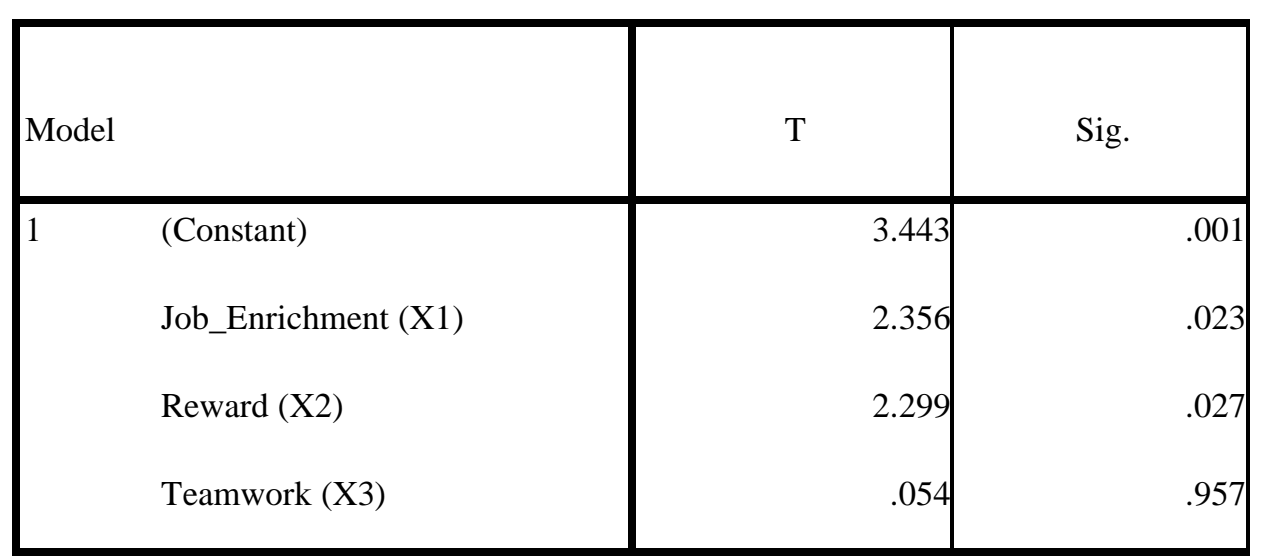

a. Dependent Variable: Employee_Engagement (Y)

Sumber: Hasil Pengolahan dengan SPSS 16.0 (2022)

Berdasarkan Tabel 4, hasil uji t maka dapat ditarik kesimpulan, sebagai berikut:

a. Pengaruh Job Enrichment (X1) terhadap Employee Engagement (Y)

Hasil uji-t menunjukkan bahwa variabel job enrichment (X1) memiliki t-hitung sebesar 2,356. Dengan nilai t-tabel sebesar 2,019 diketahui bahwa nilai t-hitung > nilai t-tabel. Karena nilai signifikansi job enrichment lebih kecil dari 0,05 atau 0,023, maka terima Ha dan tolak Ho. Dengan demikian, dapat dinyatakan bahwa variabel job enrichment berpengaruh positif dan signifikan terhadap employee engagement. 
b. Pengaruh Reward (X2) terhadap Employee Engagement (Y)

Temuan uji-t menunjukkan bahwa variabel reward (X2) memiliki t-hitung sebesar 2,299. Dengan nilai t-tabel sebesar 2,019 diketahui bahwa nilai t-hitung > nilai t-tabel. Terima Ha dan tolak Ho karena nilai signifikansi t dari variabel reward lebih kecil dari 0,05 yaitu sebesar 0,027 . Dengan demikian dapat dinyatakan bahwa variabel reward berpengaruh positif dan signifikan terhadap employee engagement.

c. Pengaruh Teamwork (X3) terhadap Employee Engagement (Y)

Reward (X2) memiliki nilai t-hitung sebesar 0,054 dan nilai t-tabel sebesar 2,019 yang berarti nilai thitung lebih kecil dari nilai tabel. Tolak Ha karena Ho memiliki nilai signifikansi t reward lebih besar dari 0,05 yaitu 0,957. Akibatnya, ada sedikit bukti bahwa faktor teamwork dan employee engagement memiliki hubungan yang signifikan.

Tabel 5. Hasil Uji F.

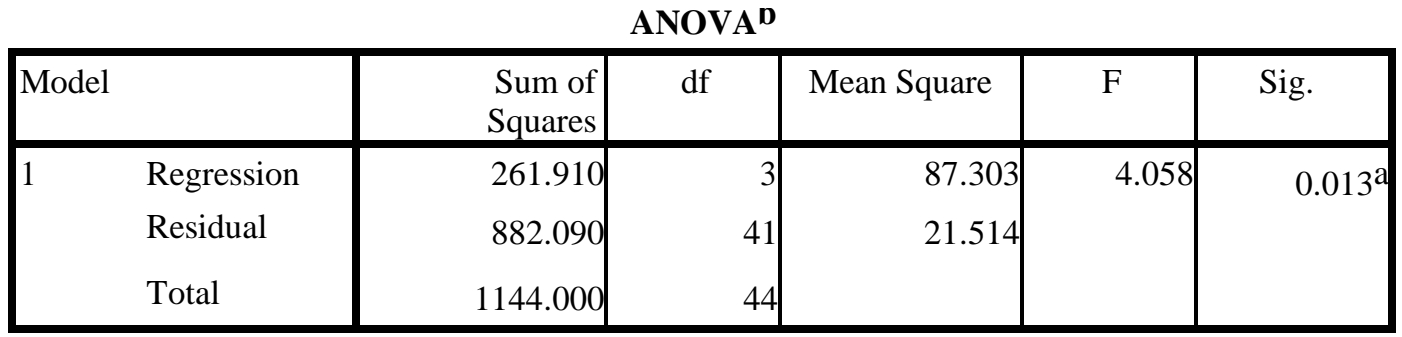

a. Predictors: (Constant), Teamwork (X3), Reward (X2), Job_Enrichment (X1)

b. Dependent Variable: Employee_Engagement (Y)

Sumber: Hasil Pengolahan dengan SPSS 16.0(2022)

Berdasarkan Tabel 5, hasil uji F maka dapat ditarik kesimpulan bahwa nilai signifikasi yang diperoleh sebesar 0,013. Nilai ini jauh lebih kecil dari 0,05 sehingga dapat disimpulkan bahwa terima Ha dan tolak Ho artinya berpengaruh signifikan. Berdasarkan nilai F-hitung, besar nilai F-hitungsebesar 4.058, yaitu nilai F-hitung > F-tabel. Nilai F-hitung > F-tabel, $4.058>2.832$. Jumlah sampel dalam penelitian ini sebanyak 45 responden, dimana $\mathrm{df}(1)=\mathrm{n}-\mathrm{k}=45-4=41$. Dihitung dengan memasukkan rumus $=\mathrm{FINV}$ $(0,05,3,41)$ ke dalam Ms. Excel, nilai F-tabelnya adalah 2,832. Dapat dikatakan bahwa job enrichment (X1), reward (X2), dan teamwork (X3) semuanya bekerja bersama untuk meningkatkan employee engagement (Y).

Tabel 6. Hasil Uji F.

Model Summaryb

\begin{tabular}{|l|r|r|r|r|}
\hline Model & $\mathrm{R}$ & R Square & \multicolumn{1}{|c|}{$\begin{array}{c}\text { Adjusted R } \\
\text { Square }\end{array}$} & $\begin{array}{c}\text { Std. Error of the } \\
\text { Estimate }\end{array}$ \\
\hline 1 & $0.478^{\mathrm{a}}$ & 0.229 & 0.173 & 4.638 \\
\hline
\end{tabular}

a. Predictors: (Constant), Teamwork (X3), Reward (X2), Job_Enrichment (X1)

b. Dependent Variable: Employee_Engagement (Y)

Sumber: Hasil Pengolahan dengan SPSS 16.0 (2022)

Berdasarkan Tabel 6, hasil uji determinasi dapat dilihat bahwa angka adjusted $R$ square 0.229 yang mengartikan bahwa 22,9\% employee engagement dapat diperoleh dan dijelaskan oleh job enrichment, reward, dan teamwork. Sedangkan sisa nya $77,1 \%$ dijelaskan oleh faktor lain yang tidak dibahas seperti senior leader, manajer yang efektif dan peduli terhadap kesejahteraan karyawan.

\subsection{Hubungan Job Enrichment Terhadap Employee Engagement}

Hipotesis $\mathrm{H} 1$ yang diajukan penulis dalam penelitian ini adalah bahwa job enrichment berpengaruh positif dan signifikan terhadap employee engagement pada PT Nusantara Berlian Motor. Berdasarkan hasil analisis data yang terkumpul, jelas bahwa variabel job enrichment memiliki koefisien regresi 0,373, 
menunjukkan bahwa pengayaan pekerjaan berpengaruh positif terhadap employee engagement, sehingga peningkatan job enrichment juga akan meningkatkan employee engagement. Hasil uji t menunjukkan bahwa t-hitung job enrichment sebesar 2,356 dengan nilai t-tabel 2,019. Nilai t-hitung $>t$-tabel yaitu sebesar $2,356>2,019$ pada signifikasi $0,023<0,05$ yang artinya terima Ha dan tolak Ho. Jadi dapat diambil kesimpulan bahwa job enrichment secara parsial dapat mempengaruhi employee engagement. Regresi linier berganda dan uji t menunjukkan bahwa job enrichment memiliki pengaruh yang agak menguntungkan dan signifikan secara statistik terhadap employee engagement di PT Nusantara Berlian Motor. Dari jawaban kuisioner yang diisi oleh responden, karyawan tidak setuju jika diberikan wewenang dalam mengambil keputusan otonom dikarenakan keputusan tetap berada pada pimpinan perusahaan. Jika job enrichment ditingkatkan di PT Nusantara Berlian Motor maka karyawan akan antusias dengan pekerjaan yang diberikan kepada mereka, dan karyawan akan merasa bangga dengan pekerjaannya serta karyawan dapat meningkatkan rasa tanggung jawab atas apa yang sudah menjadi tanggung jawab pekerjaannya.

\subsection{Hubungan Reward Terhadap Employee Engagement}

Hipotesis peneliti $\mathrm{H} 2$ adalah bahwa secara parsial reward berpengaruh positif dan signifikan secara statistik terhadap employee engagement pada PT Nusantara Berlian Motor. Berdasarkan hasil analisis dari pengujian yang dilakukan, diketahui bahwa variabel reward memiliki koefisien regresi sebesar 0,273, yang menunjukkan bahwa reward berpengaruh positif terhadap employee engagement, yang berarti bahwa peningkatan reward yang diberikan kepada karyawan juga akan meningkatkan employee engagement. Hasil uji t menunjukkan bahwa t-hitung reward sebesar 2,299 dengan nilai t-tabel 2,019. Nilai t-hitung $>\mathrm{t}$-tabel yaitu sebesar 2,299 > 2,019 pada signifikasi 0,027 < 0,05 yang artinya terima Ha dan tolak Ho. Jadi dapat diambil kesimpulan bahwa reward secara parsial dapat mempengaruhi employee engagement. Hasil regresi linier berganda dan uji t menunjukkan bahwa reward secara parsial berpengaruh positif dan signifikan secara statistik terhadap employee engagement pada PT Nusantara Berlian Motor. Dari jawaban kuisioner yang diisi oleh responden, dapat dilihat bahwa perusahaan belum memberikan reward yang sesuai dengan prestasi karyawan dan gaji yang diberikan belum sesuai dengan keahlian yang dimiliki. Jika pemberian reward sudah ditingkatkan dalam perusahaan dan sudah disesuaikan dengan prestasi atau pencapain karyawan, maka karyawan merasa dihargai dalam setiap melakukan pekerjaan yang mereka kerjakan serta karyawan memiliki semangat dalam menyelesaikan tugas dan tanggung jawab mereka masing-masing. Ini dikarenakan ada nya umpan balik dari karyawan terhadap perusahaan maupun sebaliknya.

\subsection{Hubungan Teamwork Terhadap Employee Engagement}

Hipotesis $\mathrm{H} 3$ yang diajukan peneliti dalam penelitian ini adalah teamwork secara parsial tidak terdapat pengaruh yang signifikan terhadap employee engagement di PT Nusantara Berlian Motor. Berdasarkan hasil analisis dari hasil pengujian yang dilakukan diketahui bahwa variabel teamwork memiliki nilai regresi 0,007 yang mengartikan bahwa teamwork tidak berpengaruh terhadap employee engagement. Hasil uji t menunjukkan bahwa t-hitung teamwork sebesar 0,054 dengan nilai ttabel 2,019. Nilai t-hitung < t-tabel yaitu sebesar 0,054<2,019 pada signifikasi 0,0957>0,05 yang artinya terima Ho dan tolak Ha. Sehingga hipotesis yang diajukan tidak terbukti bahwa teamwork bepengaruh terhadap employee engagement. Regresi linier berganda dan uji t menunjukkan bahwa teamwork memiliki dampak yang dapat diabaikan terhadap employee engagement di PT Nusantara Berlian Motor. Dari jawaban kuisioner yang diisi oleh responden, karyawan mengharapkan ada nya kerja sama yang baik saat menjalankan tugas dan sikap saling berkontribusi dalam menjalankan pekerjaan karena dalam menyelesaikan pekerjaan adanya ketergantungan urutan dalam menjalankan pekerjaan. Jika teamwork dalam PT Nusantara Berlian Motor sudah ditingkatkan maka akan berdampak kepada kegiatan dalam perusahaan, karena karyawan merasa senang setiap melakukan pekerjaan mereka dan merasa percaya diri dengan tugas yang diberikan berdasarkan kemampuan mereka.

\subsection{Hubungan Job Enrichment, Reward dan Teamwork Terhadap Employee Engagement}

Employee engagement pada PT Nusantara Berlian Motor berpengaruh positif dan signifikan secara statistik terhadap job enrichment, reward dan teamwork, menurut hipotesis peneliti H4. Terdapat korelasi positif antara employee engagement dengan job enrichment, reward, dan teamwork, sebagaimana ditunjukkan oleh hasil analisis dari pengujian yang telah dilakukan hingga saat ini. Uji F menunjukkan bahwa F-hitung yang dicapai adalah 4,058. Nilai F-hitung yang didapat jauh lebih besar dari nilai F-tabel yang di dapat sebesar 2,832. Nilai signifikan yang dihasilkan sebesar 0,013 yang dimana nilai signfikan yang didapat jauh lebih kecil dari standart nilai signifkan sebesar 0,05 . Oleh karena dapat disimpulkan bahwa F-hitung $>$ F-tabel yaitu sebesar 4,058 $>2,832$ pada signifikasi $0,013<0,05$ yang artinya terima Ha 
dan tolak Ho. Sehingga job enrichment, reward dan teamwork secara simultan berpengaruh signifikan terhadap employee engagement. Maka dari hasil penelitian ini dapat disimpulkan bahwa job enrichment, reward dan teamwork berpengaruh positif secara simultan terhadap employee engagement. Jika semua bagian dalam perusahaan berusaha untuk sejalan dalam mencapai tujuan-tujuan yang akan dicapai, maka akan berdampak kepada operasional yang berjalan didalam perusahaan.

\section{Conclusion}

Di PT Nusantara Berlian Motor, job enrichment memiliki dampak besar pada employee engagement. Memberikan reward kepada karyawan PT Nusantara Berlian Motor memiliki pengaruh yang baik dan signifikan terhadap employee engagement. Karyawan PT Nusantara Berlian Motor tidak terlalu termotivasi oleh teamwork. employee engagement di PT Nusantara Berlian Motor didorong oleh kombinasi job enrichment, reward, dan teamwork.

\section{References}

[1] Bakker AB, Leiter MP. Work engagement : A handbook of Essential Theory And Research. New York: Pscyhology Press; 2010.

[2] Dalal RS, Brummel BJ, Baysinger M, LeBreton JM. The relative importance of employee engagement, other job attitudes, and trait affect as predictors of job performance. Journal of Applied Social Psychology. 2012; 42(S1), E295 - E325.

[3] Ghozali I. Aplikasi Analisis Multivariate Dengan Program SPSS. Semarang: Badan Penerbit Universitas Diponegoro; 2011.

[4] Ghozali I. Aplikasi Analisis Multivariate dengan Program IBM SPSS. Yogyakarta: Universitas Diponegoro; 2012.

[5] ___ Aplikasi Analisis Multivariete Dengan Program (IBM SPSS). Edisi 8. Semarang: Badan Penerbit Universitas Diponegoro; 2016.

[6] Marpaung M. Pengaruh Kepemimpinan Dan Team Work Terhadap Kinerja Karyawan Di Koperasi Sekjen Kemendikbud Senayan Jakarta. Jurnal Ilmiah WIDYA. 2014; 2(1).

[7] Ram P, Prabhakar GV. The role employee engagement in work-related outcomes. Interdisciplinary Journal of Research ini Business. 2011; 1(3):47 - 61.

[8] Shorbaji R, Messarra L, Karkoulian S. Core-self evaluation: Predictor of employee engagement. The Business Review. 2011; 17(1):276 - 283.

[9] Sugiyono. Metode Penelitian Kombinasi (Mix Methods). Bandung: Alfabeta; 2015.

[10] Vibrayani. Peran Transformasional Leadership terhadap Employee Engagement. UGM: Tesis Fakultas Ekonomi dan Bisnis; 2012.

[11] Van Rooy DL, Whitman DS, Hart D, Caleo S. Measuring employee engagement during a financial downturn: Business imperative or nuisance? Journal of Business and Psychology. 2011; 26:147 - 152.

[12] Arif S, Dheasey A, Leonardo BH, Azis F. Pengaruh Kompensansi dan Teamwork Terhadap Produktivitas Kerja Karyawan Melalui Loyalitas Karyawan pada CV. Mawar Semarang. Journal of managemen. 2017; 13(3). 